\title{
Annals of Pharmacology and Pharmaceutics
}

\section{Inhibition of the Binding of Variants of SARS-CoV-2 Coronavirus Spike Protein to a Human Receptor by Chlorine Dioxide}

Norio Ogata* and Takanori Miura

Department of R\&D, Taiko Pharmaceutical Co., Ltd, Japan

\begin{abstract}
Aim: COVID-19 caused by a new coronavirus, SARS-CoV-2, has become an ongoing worldwide pandemic. A safe and potent virucidal disinfection system is urgently needed to protect the population from the virus. Chlorine Dioxide (ClO2) is a powerful disinfectant that is known to inactivate both viruses and bacteria. The aim of this study was to investigate whether chlorine dioxide inhibits the binding of the receptor-binding domain of the Spike protein (S protein) from variant coronavirus (British and South African variants) to human receptor, Angiotensin-Converting Enzyme 2 (ACE2).
\end{abstract}

Materials and Methods: In vitro experiments to determine binding of the purified receptor-binding domain of spike protein to ACE2 were performed in the presence of various concentrations of chlorine dioxide. Purified spike proteins from the British and South African variants were used. Spike protein coated onto a microtiter plate was treated with chlorine dioxide aqueous solution or chlorine dioxide spray solution.

Result: Binding of variant spike proteins was inhibited in a concentration-dependent manner (50\% Inhibitory Concentration (IC50) of $7.6 \mu \mathrm{mol} / \mathrm{L}$ and $5.8 \mu \mathrm{mol} / \mathrm{L}$ for the British and the South African variants, respectively).

Conclusion: These findings show that chlorine dioxide aqueous solution can inactivate the binding of the variant spike proteins to the human ACE2 receptor protein, indicating that this strategy may be useful in blocking the transmission of variant SARS-CoV-2 viruses.

OPEN ACCESS

*Correspondence:

Norio Ogata, Department of $R \& D$, Taiko Pharmaceutical Co., Ltd., 1-2-1 Hikaridai, Seikacho, 619-0237 Kyoto, Japan, Tel: 8177498 2716; Fax: 81

77498 2737;

E-mail:nogata7@yahoo.co.jp Received Date: 21 May 2021 Accepted Date: 16 Jun 2021 Published Date: 18 Jun 2021

Citation:

Ogata N, Miura T. Inhibition of the Binding of Variants of SARS-COV-2 Coronavirus Spike Protein to a Human Receptor by Chlorine Dioxide. Ann

Pharmacol Pharm. 2021; 6(1): 1199.

Copyright $\odot 2021$ Norio Ogata. This is an open access article distributed under

the Creative Commons Attribution

License, which permits unrestricted

use, distribution, and reproduction in any medium, provided the original work is properly cited.
Keywords: Chlorine dioxide; COVID-19; SARS-CoV-2; Virus; Disinfection; IC50

\section{Introduction}

Coronavirus Disease 2019 (COVID-19) is caused by Severe Acute Respiratory Syndrome Coronavirus 2 (SARS-CoV-2) and has become a serious health issue since its emergence in late 2019 $[1,2]$. The outbreak of this disease originated in Wuhan, Hubei Province, China, before spreading rapidly throughout the world [2]. The COVID-19 pandemic was declared an international emergency in 2020 [3]. As of May 2021, global death toll due to COVID-19 is estimated to be approximately 3.3 million [4]. SARS-CoV-2 is an enveloped virus and has a single-stranded negative-sense RNA genome of 29.9 kilobases [5]. The virus attaches to the host cell surface of type I and II pneumocytes, endothelial cells and ciliated bronchial epithelial cells [6]. Although several vaccines against the disease have already been developed and administered [7], the pandemic has not yet ended. Furthermore, currently variant types of SARS-CoV-2 virus have been reported from England (B.1.1.7 variant) and South Africa (variant B.1.351) that appear to be spread more readily than the original virus [8]. Both of these variants carry a common mutation (N501Y) in the Receptor-Binding Domain (RBD) of the spike protein (S protein) [5]. This mutation is important in binding of the spike protein to human cell surface receptor, Angiotensin-Converting Enzyme 2 (ACE2), a type I transmembrane glycoprotein with carboxypeptidase activity [5].

To control the spread of COVID-19, it is essential to develop and deploy safe but effective disinfectants against the virus alongside novel antiviral drugs and vaccines [8]. While ethanol is known to be effective against the virus [9], it cannot eradicate the virus present in the air. Chlorine Dioxide (ClO2) (CD) is a water-soluble yellow gas at room temperature and is a stable free radical [10]. CD can be used as a gas or an aqueous solution to inactivate both viruses and bacteria [11-15]. The powerful disinfection action of $\mathrm{CD}$ against microbes is due to its strong oxidizing activity against proteins [16]. Moreover, safe and permissible concentrations of CD have been well documented 
[17]. Here, we demonstrate that $\mathrm{CD}$ aqueous solutions can inactivate the binding of the spike proteins of both the British and South African variant to human $\mathrm{ACE} 2$ in in vitro experiments, suggesting it may be effective at inhibiting infection of the SARS-CoV-2 virus.

\section{Materials and Methods}

\section{Chemicals}

$\mathrm{CD}$, prepared in our laboratory as described previously [16], was dissolved in purified water and stored at $4^{\circ} \mathrm{C}$ in a tightly capped amber bottle. The stock $\mathrm{CD}$ was diluted in purified water to the desired concentration immediately prior to use. A commercially available CD spray solution sold under the brand name of Cleverin (Taiko Pharmaceutical, Osaka, Japan) was also tested. The composition of Cleverin was $1.48 \mathrm{mmol} / \mathrm{L} \mathrm{CD}, 66.34 \mathrm{mmol} / \mathrm{L}$ sodium chlorite, 8.70 $\mathrm{mmol} / \mathrm{L}$ sodium dihydrogen phosphates, $0.24 \%$ (weight/weight) decaglycerol monolaurate, $0.06 \%$ silicone and $98.97 \%$ water, $\mathrm{pH}$ 6.01. A tightly capped bottle of the spray solution made 3 years ago, kept at room temperature and protected from the light was used. The $\mathrm{CD}$ concentration of the spray solution at the time of the experiment was $1.80 \mathrm{mmol} / \mathrm{L}$ (121 ppm (weight/weight)). The spray solution was diluted as required with purified water immediately prior to the experiment.

\section{Binding assay}

The spike protein binding assay kit was purchased from BPS Bioscience (San Diego, California, USA). The kit codes for the British and South African variant assay were 78140 and 78151, respectively. The kits consisted of purified Receptor-Binding Domain (RBD) of spike proteins derived from the corresponding variant virus. The kit was used as recommended by the manufacturer with some modifications. The spike protein RBD provided in the kit was first coated onto a 96-well microtiter plate from the kit as indicated by the manual. A $50 \mu \mathrm{L}$ aliquot of $\mathrm{CD}$ or $\mathrm{CD}$ spray solution diluted to an appropriate concentration was placed in each well and incubated at $25^{\circ} \mathrm{C}$ for $5 \mathrm{~min}$. Next, a $20 \mu \mathrm{L}$ aliquot of $10 \mathrm{mmol} / \mathrm{L}$ sodium thiosulfate in Blocking Buffer 2 provided in the kit was added to each well to terminate the reaction of $\mathrm{CD}$ with the protein. Under this condition, the $\mathrm{CD}$ is rapidly converted to $\mathrm{ClO} 2$ - and becomes unreactive with proteins [16]. Next, a $35 \mu \mathrm{L}$ aliquot of biotin-labeled ACE2 diluted to $1.5 \mu \mathrm{g} / \mathrm{mL}$ by Blocking Buffer 2 was added to each well. Biotin-labeled ACE2 was then bound to streptavidin-labeled horseradish peroxidase and detected using a substrate of the horseradish peroxidase supplied in the kit. The Chemiluminescence signal was measured after $1 \mathrm{~min}$ using a luminometer (model SH-9000; Corona Electric, Hitachinaka, Ibaraki, Japan). Each concentration of CD was assayed in four wells $(n=4)$. Because the chemiluminescence intensity fluctuated between experiments, the final data was normalized (i.e. $0 \mu \mathrm{g} / \mathrm{ml} \mathrm{CD}$ as $100 \%$ ).

\section{Results and Discussion}

As shown in Figure 1, the intensity of the binding of human ACE2 protein to the spike protein RBD decreased with increasing concentrations of $\mathrm{CD}$. The concentration of aqueous $\mathrm{CD}$ solution required to give $50 \%$ binding inhibition (IC50) was $7.6 \mu \mathrm{mol} / \mathrm{L}$ and $5.8 \mu \mathrm{mol} / \mathrm{L}$ for the British and South African variant, respectively (Table 1). An inhibitory effect of CD was also observed using the CD spray solution (Figure 2). Specifically, IC50 for the binding of ACE2 to the spike protein $\mathrm{RBD}$ was $15.3 \mu \mathrm{mol} / \mathrm{L}$ and $4.7 \mu \mathrm{mol} / \mathrm{L}$ for the British and South African variant, respectively (Table 1). Moreover, binding of the Wuhan strain spike protein RBD to ACE2 was also inhibited by the CD aqueous solution with an IC50 of $6.5 \mu \mathrm{mol} / \mathrm{L}$
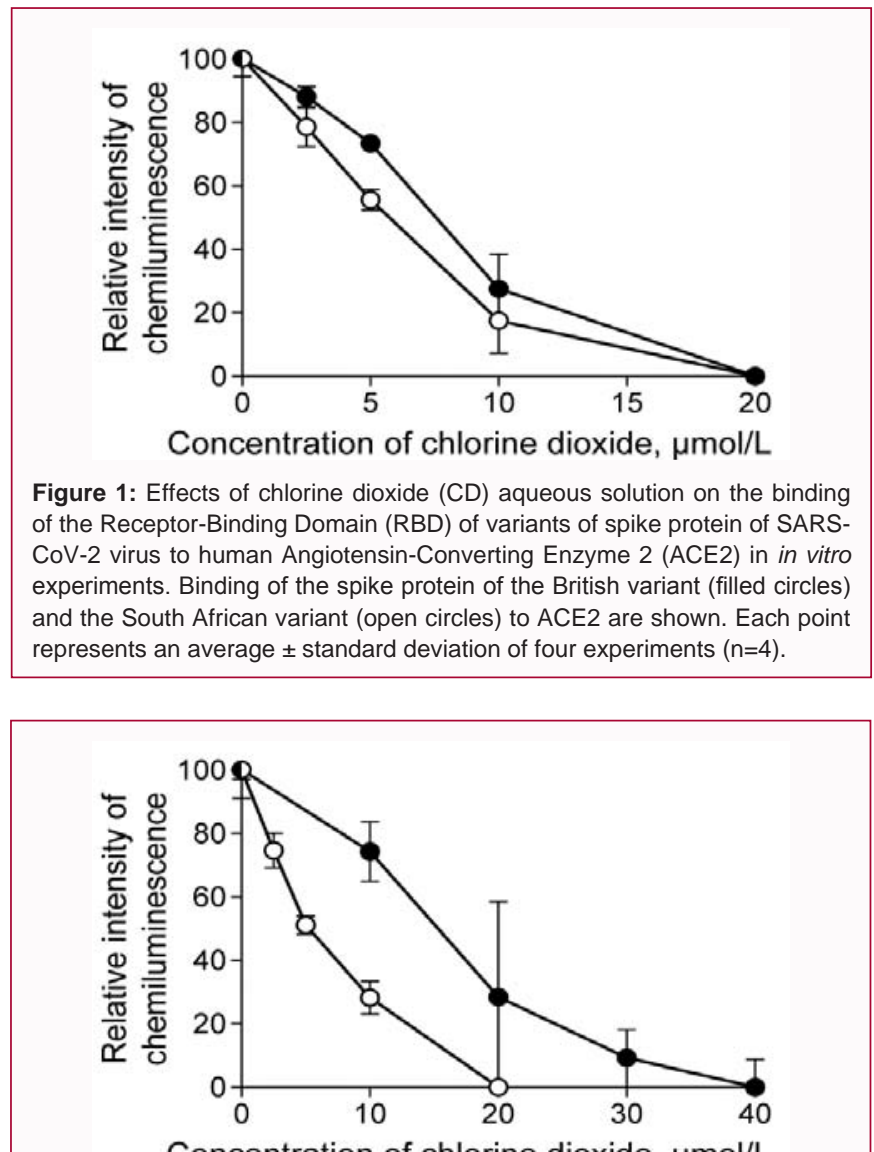

Figure 2: Effects of the Chlorine Dioxide (CD) spray solution on the binding of the Receptor-Binding Domain (RBD) of variants of spike protein of SARSCoV-2 virus to human Angiotensin-Converting Enzyme 2 (ACE2) in in vitro experiments. Binding of the spike protein of the British variant (filled circles) and the South African variant (open circles) to ACE2 are shown. Each point represents an average \pm standard deviation of four experiments $(n=4)$.

Table 1: The concentration of Chlorine Dioxide (CD) aqueous solution required to inhibit binding of the receptor-binding domain of variant SARS-CoV-2 spike proteins (S proteins) to human receptor protein ACE2 by $50 \%$ (IC50) is shown.

\begin{tabular}{|c|c|}
\hline & $\mathrm{IC}_{50}(\mu \mathrm{mol} / \mathrm{L})$ \\
\hline \multicolumn{2}{|c|}{ CD aqueous solution against } \\
\hline British variant & 7.6 \\
\hline South African variant & 5.8 \\
\hline \multicolumn{2}{|c|}{ CD spray solution against } \\
\hline British variant & 15.3 \\
\hline South African variant & 4.7 \\
\hline
\end{tabular}

Variants of spike protein Receptor-Binding Domain (RBD) were treated with either Chlorine Dioxide (CD) aqueous solution or CD spray solution at various concentrations, and then assayed for its binding ability to the receptor protein ACE2

(Ogata N, unpublished data). There were slight differences in the inhibitory effect between aqueous $\mathrm{CD}$ and the $\mathrm{CD}$ spray solution in these experiments. The observed differences may be due to the effect of other constituents in the spray solution, which are added to prolong the shelf life of the product. These results suggest all the CD solutions are effective in inactivating the binding of the SARS-CoV-2 virus to human cell receptor ACE2. As such, CD is likely to have an inhibitory action on the infection of the virus.

The spike protein RBD of SARS-CoV-2 virus is located in the S1 
subunit of the spike protein, and the region of RBD that interacts with ACE2 consists of a small patch of 25 amino acid residues [18].

The asparagine 501 (N501) residues, which is mutated to tyrosine in both viral variants, forms part of the RBD patch region of the spike protein [5]. The N501Y mutation is thought to result in enhanced viral transmissibility by increasing the binding affinity to human ACE2 [18]. Furthermore, it is worth noting that this mutation allows the virus to escape from many antibodies raised against the virus [18], suggesting poor effectiveness of vaccines against these variant strains of SARS-CoV-2 virus. We previously demonstrated that the binding of the spike protein RBD of the Wuhan strain to human ACE2 is inhibited by CD aqueous solution [19]. These findings suggested CD may be useful as a disinfectant against virus. Although the mechanism of this inhibition has not been elucidated, we speculated that it may involve oxidization of the tyrosine 453 residue of the RBD of the spike protein, which forms a hydrogen bond with ACE2 [19]. Indeed, $\mathrm{CD}$ is known to oxidize tyrosine residues in proteins [16]. Because asparagine 501 is mutated to tyrosine $(\mathrm{Y})$ in the variant strains, treatment of the virus with CD may also oxidize 501Y. Given that vaccines appear to have diminished effectiveness against the variant viruses, disinfection systems employing $\mathrm{CD}$ may be invaluable. It is also important to note that $\mathrm{CD}$ is a gas at room temperature and can be used in this form to inactivate microbes floating in the air at concentrations deemed safe to human health [17]. As such, gaseous $\mathrm{CD}$ could be used to inactivate the SARS-CoV-2 virus floating in the air of a crowded room.

\section{Conclusion}

CD solution, whether in water or as a formulated spray solution in water, was found to potently inhibit the binding of spike protein RBD to human receptor protein ACE2 in a concentration-dependent manner. These findings suggest $\mathrm{CD}$ may be invaluable for inhibiting the infection of SARS-CoV-2 virus to human.

\section{Acknowledgement}

The authors are employees of Taiko Pharmaceutical Co., Ltd. This work was supported by the company.

\section{References}

1. Wang C, Horby PW, Hayden FG, Gao GF. A novel coronavirus outbreak of global health concern. Lancet. 2020;395(10223):470-3.

2. Guan WJ, Ni ZY, Hu Y, Liang WH, Ou CQ, He JX, et al. Clinical characteristics of coronavirus disease 2019 in China. N Engl J Med. 2020;382:1708-20.

3. Trivedi N, Verma A, Kumar D. Possible treatment and strategies for COVID-19: Review and assessment. Eur Rev Med Pharmacol Sci. 2020;24(23):12593-608.

4. COVID live update. Available from: www.worldometers.info > coronavirus
5. Naqvi AAT, Fatima K, Mohammad T, Fatima U, Singh IK, Singh A, et al. Insights into SARS-CoV-2 genome, structure, evolution, pathogenesis and therapies: Structural genomics approach. Biochim Biophys Acta Mol Basis Dis. 2020;1866(10):165878.

6. Soni S, Jiang Y, Tesfaigzi Y, Hornick JL, Çataltepe S. Comparative analysis of ACE2 protein expression in rodent, non-human primate, and human respiratory tract at baseline and after injury: A conundrum for COVID-19 pathogenesis. PLoS One. 2021;16(2):e0247510.

7. Wibawa T. COVID-19 vaccine research and development: ethical issues. Trop Med Int Health. 2021;26(1):14-9.

8. Wang P, Nair MS, Liu L, Iketani S, Luo Y, Guo Y, et al. Increased resistance of SARS-CoV-2 variants B.1.351 and B.1.1.7 to antibody neutralization. BioRxiv. 2021;2021.01.25.428137.

9. Hirose R, Ikegaya H, Naito Y, Watanabe N, Yoshida T, Bandou R, et al. Survival of SARS-CoV-2 and influenza virus on the human skin: Importance of hand hygiene in COVID-19. Clin Infect Dis. 2020;ciaa1517.

10. Shimakura H, Ogata N, Kawakita Y, Ohara K, Takeda S. Determination of the structure of liquids containing free radical molecules: Intermolecular correlations in liquid chlorine dioxide. Molecular Physics. 2013;111(8):1015-22.

11. Ogata N, Shibata T. Protective effect of low-concentration chlorine dioxide gas against influenza A virus infection. J Gen Virol. 2008;89(Pt 1):60-7.

12. Ogata N, Sakasegawa M, Miura T, Shibata T, Takigawa Y, Taura K, et al. Inactivation of airborne bacteria and viruses using extremely low concentrations of chlorine dioxide gas. Pharmacology. 2016;97(5-6):301-6.

13. Ogata N. Inactivation of influenza virus haemagglutinin by chlorine dioxide: Oxidation of the conserved tryptophan 153 residue in the receptor-binding site. J Gen Virol. 2012;93(Pt 12):2558-63.

14. Morino H, Fukuda T, Miura T, Shibata T. Effect of low-concentration chlorine dioxide gas against bacteria and viruses on a glass surface in wet environments. Lett Appl Microbiol. 2011;53(6):628-34.

15. Morino H, Fukuda T, Miura T, Lee C, Shibata T, Sanekata T. Inactivation of feline calicivirus, a norovirus surrogate, by chlorine dioxide gas. Biocontrol Sci. 2009;14(4):147-53.

16. Ogata N. Denaturation of protein by chlorine dioxide: Oxidative modification of tryptophan and tyrosine residues. Biochemistry. 2007;46(16):4898-911.

17. Akamatsu A, Lee C, Morino H, Miura T, Ogata N, Shibata T. Six-month low level chlorine dioxide gas inhalation toxicity study with two-week recovery period in rats. J Occup Med Toxicol. 2012;7:2.

18. Zhou D, Dejnirattisai W, Supasa P, Liu C, Mentzer AJ, Ginn HM, et al. Evidence of escape of SARS-CoV-2 variant B.1.351 from natural and vaccine-induced sera. Cell. 2021;184(9):2348-61.e6.

19. Ogata N, Miura T. Inhibition of the binding of spike protein of SARSCoV-2 coronavirus to human angiotensin-converting enzyme 2 by chlorine dioxide. Ann Pharmacol Pharm. 2020;5(5):1195. 